\title{
Fourwing Saltbush Revegetation Trials in Southern Arizona ${ }^{1}$
}

\section{DWIGHT R. CABLE}

Principal Range Scientist, Rocky Mountain Forest and Range Experiment Station,2 Tucson, Arizona.

\section{Highlight}

Fourwing saltbush was seeded and transplanted into native stands of (a) almost pure creosotebush and (b) velvet mesquite with burroweed understory, in southern Arizona. Burroweed and creosotebush were controlled by picloram spray and by grubbing. The mesquite was killed on half of the burroweed plots. Establishment and survival of saltbush was much higher on the creosotebush site than on the mesquite site, presumably because the calcareous $(\mathrm{pH} 8.0+$ ) soil at the creosotebush site was more suitable than the non-calcareous neutral soil at the mesquite site. Transplants survived much better on grubbed plots than on sprayed or check plots, and seedlings on sprayed or grubbed plots than on check plots. However, after 3 years the stands were reduced to 650 and 46 plants per acre on the creosotebush and mesquite-burroweed area respectively.

Fourwing saltbush (Atriplex canescens (Pursh) Nutt.) ${ }^{3}$ is one of the most widely distributed and important shrubs on western ranges. It has been used for revegetation many times with varying degrees of success. Springfield (1970) presents a thorough summary of the present state of knowledge relating to the germination and establishment of fourwing saltbush, but most of his work was done in New Mexico at

${ }^{1}$ Received May 12, 1971.

${ }^{2}$ Forest Service, U.S. Department of Agriculture, with central headquarters at Fort Collins, in cooperation with Colorado State University. Author stationed at Tucson in cooperation with the University of Arizona.

${ }^{3}$ Nomenclature follows Kearney and Peebles, 1951. elevations above 6000 feet and annual precipitation from 11-15 inches. Although precise recommendations for hotter and drier semidesert conditions are not available, fourwing saltbush grows naturally in the vicinity of Tucson, Arizona at an elevation of about 2400 feet and annual precipitation of about 11 inches. It thus would appear to be adapted for use on similar areas in the semidesert Southwest, if suitable methods for establishing it can be developed.

Exploratory studies designed to determine some of the environmental limitations for establishment of fourwing saltbush in the semidesert Southwest were conducted from 1966 to 1969 on the
Santa Rita Experimental Range in southern Arizona. The long-range objective was to investigate the feasibility of replacing creosotebush (Larrea tridentata (DC.) Coville), velvet mesquite (Prosopis juliflora var. velutina (Woot.) Sarg.), and burroweed (Aplopappus tenuisectus (Greene) Blake), species of little or no grazing value, with a highly desirable forage species.

Two methods of establishment were tried: (I) direct seeding and (2) planting transplants. These methods were tried on two sites: (a) a creosotebush site with little or no understory vegetation and (b) a velvet mesquite site with an understory of burroweed and a sparse mixture of native perennial grasses (Fig. 1).

Although these trials must be considered failures from the standpoint of permanent establishment of fourwing saltbush, the initial establishment under the varying site conditions and the imposed treatment conditions helps to delineate some of the tolerances and limitations of fourwing saltbush for revegetation in this part of the Southwest. It thus should be of interest to those concerned with range improvement in the semidesert.

\section{Study Areas and Methods}

Creosotebush Site

This area, located at an elevation of $3240 \mathrm{ft}$, receives an average annual rainfall of 13.25 inches, of which about $57 \%$ falls during the 

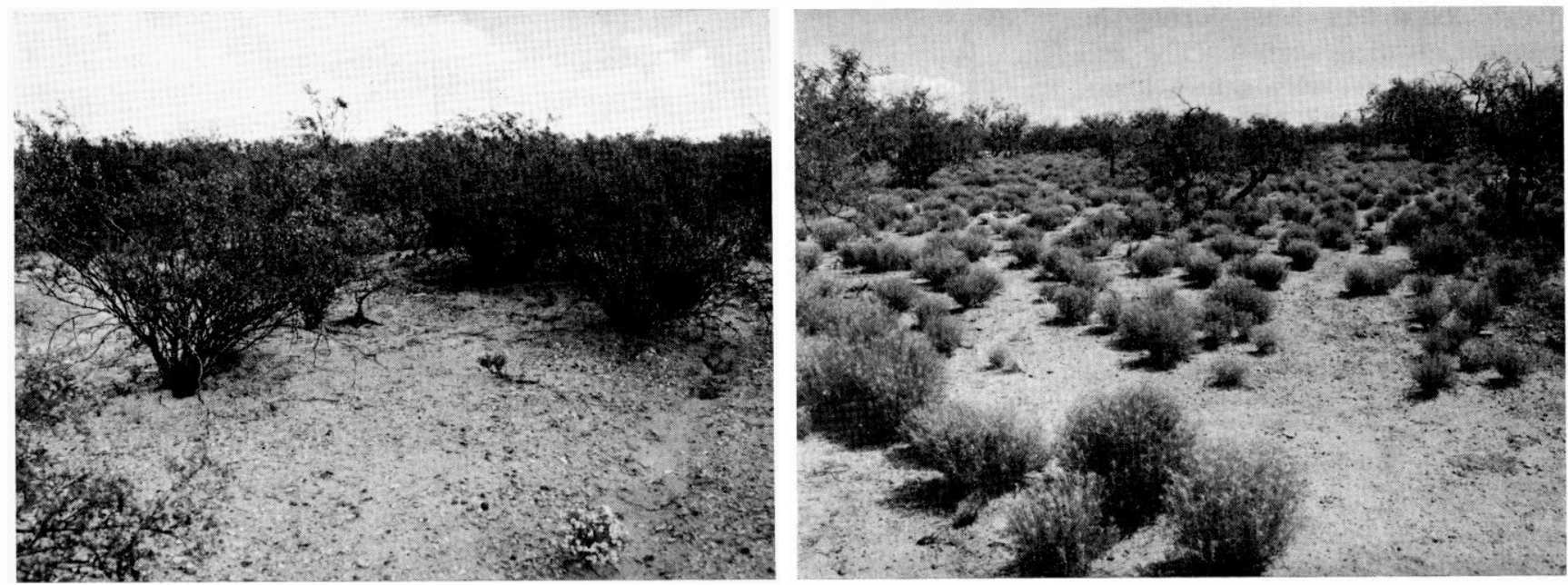

Fig. 1. Natural vegetation before treatment: Left Creosotebush Site. Right Mesquite-Burroweed Site.

summer growing season (June-September). The soil is of the Anthony series, very gravelly, variant, and with a gravelly fine sandy loam surface underlain by $40-50$ inches of stratified light yellowish brown fine sandy loam and very gravelly fine sandy loam. The entire profile is calcareous, $\mathrm{pH} 8.0$ in the surface to 8.2 in the subsoil (Clemmons and Wheeler, 1970).

Saltbushes were planted on $100 \times$ $100 \mathrm{ft}$ plots representing three cover conditions of creosotebush:

(1) Undisturbed creosotebush stand (check treatment).

(2) Creosotebush plants killed by foliage spray of 4-amino3,5,6-trichloropiclonic acid (picloram) $1 \mathrm{lb}$. aehg water.

(3) Creosotebush plants removed by grubbing

The treatments were applied in August 1965 and were replicated six times in a randomized block.

On each plot, 30 small saltbush plants were transplanted, one near the base of each of 10 creosotebush plants, one under the edge of the crown of each of the same 10 plants, and 10 in adjacent openings. The small saltbush plants (to $1 \mathrm{ft}$ tall) were dug from a natural stand a few miles away, and the tops were pruned back as they were dug. Near each transplant, several saltbush seeds were planted in a 3- to 4- inch-long scratch in the ground and covered $1 / 4$ to $1 / 2$ inch deep.

Saltbush transplants and seeds were planted in late January 1966. The soil was very moist from recent rains, and temperatures were comparatively low. The study area had received over 6 inches of rain in December 1965, and rainfall during the remainder of the winter and spring was above the long-time mean (Table 1). Temperatures in the top inch of soil were probably within the 55 to $75 \mathrm{~F}$ range recommended by Springfield (1969, 1970) during the last half of February and most of March. Conditions thus seemed to be optimum for successful establishment of saltbush.

An additional direct-seeding trial was made in January 1968, when hammermilled seed (18 months old) was drilled at $10 \mathrm{lb}$./acre by a rangeland drill with l-inch depth bands. ${ }^{4}$ The drill, $5 \mathrm{ft}$ wide, was pulled thru openings in the shrub stand in 15 of the 18 plots (the shrub stand was too dense in three plots). Again, rainfall during the following spring was well above the long-time mean.

Germination, establishment, and survival of seedlings and transplants were determined in June of the year of planting and the following 3 years for seed spots and transplants, and the following 2 years for the rangeland drill seeding.

\section{Mesquite-Burroweed Site}

This area, located at an elevation of $3180 \mathrm{ft}$, receives an average annual rainfall of 13.46 inches, of

${ }^{4}$ Seed furnished and drilled by SCS Plant Materials Center, Tucson.

Table 1. Seasonal precipitation (inches) at study areas.

\begin{tabular}{|c|c|c|c|c|c|c|c|c|}
\hline & \multicolumn{4}{|c|}{ Creosotebush site } & \multicolumn{4}{|c|}{ Mesquite-burroweed site } \\
\hline & $\begin{array}{l}\text { Oct.- } \\
\text { Jan. }\end{array}$ & $\begin{array}{l}\text { Feb.- } \\
\text { May }\end{array}$ & $\begin{array}{l}\text { June-- } \\
\text { Sept. }\end{array}$ & Total & $\begin{array}{l}\text { Oct.- } \\
\text { Jan. }\end{array}$ & $\begin{array}{l}\text { Feb.- } \\
\text { May }\end{array}$ & $\begin{array}{l}\text { June- } \\
\text { Sept. }\end{array}$ & Total \\
\hline $1965-66$ & 9.28 & 2.32 & 8.87 & 20.47 & wet & 2.26 & 7.89 & - \\
\hline $1966-67$ & .71 & 1.83 & 11.32 & 13.86 & .65 & .78 & 9.99 & 11.42 \\
\hline $1967-68$ & 7.36 & 3.68 & 6.71 & 17.75 & 6.70 & 3.23 & 7.82 & 17.75 \\
\hline $1968-69$ & 2.63 & 1.41 & 11.13 & 15.17 & 1.76 & 1.25 & 8.79 & 11.80 \\
\hline $1969-70$ & 1.18 & 2.02 & & & 1.75 & 1.51 & & \\
\hline $\begin{array}{c}\text { Long-tim } \\
\text { Mean }\end{array}$ & 3.60 & 2.08 & 7.57 & 13.25 & 3.04 & 1.85 & 8.57 & 13.46 \\
\hline
\end{tabular}


which about 64\% falls during the summer growing season. The soil is Eba very gravelly sandy loam, with a surface soil (4-6 inches) of dark reddish brown, granular, very gravelly sandy loam underlain by 24-30 inches of dark red and very gravelly heavy clay loam to clay. The substratum consists of 12-20 inches of dark red, very gravelly clay that is calcareous and weakly cemented $(\mathrm{pH} 7.2$ in the surface soil, 7.2-7.6 in the subsoil, and 8.0 in the calcic horizon).

On this area, a split-plot randomized block design was used so that establishment and survival of saltbush could be evaluated on plots with and without control of both velvet mesquite and burroweed. Thus, on one of each pair of large plots $(200 \times 200 \mathrm{ft}$ with six replications) mesquites were killed with a basal application of diesel oil. In the center of each large plot, three subplots $(30 \times 90 \mathrm{ft}$ each $)$ were established for burroweed control treatment: (1) no treatment (check), (2) sprayed with picloram (l lb. aehg water), and (3) grubbed. Twenty seed spots were established on each subplot, 10 under burroweed crowns and 10 in openings. Because of a shortage of saltbush transplants, only six were planted on each subplot (three under burroweed plants and three in openings) on nine of the main plots (these transplants were grown from seed in plant bands, and were 6 to 7 months old and 3 to 6 inches tall when transplanted). Seed was drilled in two swaths across all plots in January 1968 as was done on the creosotebush site. Rainfall during the years of treatment was similar on both areas, and was unusually favorable for species that germinate in cool weather.

\section{Results-Creosotebush Site}

\section{Saltbush Transplants}

Of the 180 saltbushes transplanted in January 1966 on the 6 replications of each creosotebush treatment, $42 \%$ and $46 \%$ were still alive the following June on the check and grubbed plots respec-

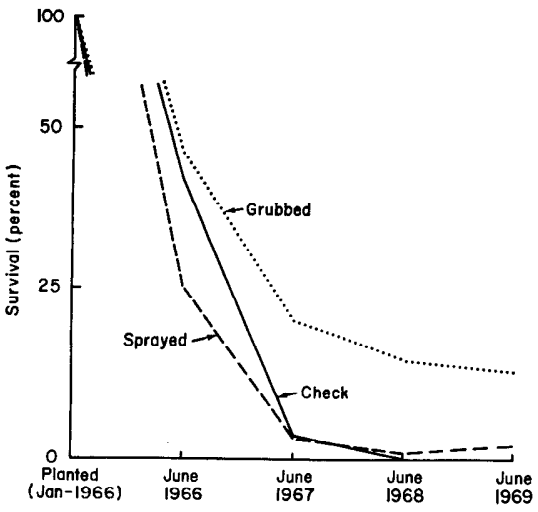

FIG. 2. Survival of saltbush transplants on creosotebush plots and on plots where creosotebush was grubbed or sprayed (positions grouped).

tively, but only $26 \%$ were alive on the sprayed plots (Fig. 2) (spray plots significantly lower than check and grub, $p=.05$ ). This difference may have been caused by residual picloram in the soil on the sprayed plots. First-year survival data at the 3 positions on the sprayed plots show that only $12 \%$ of the plants transplanted under the creosotebushes survived, compared to $32 \%$ and $35 \%$ for those transplanted at the edge of the crowns and in the openings (difference significant at $\mathrm{p}=.05)$. At these latter two exposed positions the initial concentration of picloram was relatively light because the herbicide was sprayed on the shrub crowns, and whatever picloram was in the soil probably broke down rapidly in the hot late summer months. But picloram in the soil on the shaded areas under the shrub crowns must have retained some activity at least thru the spring. Differences in first-year survival of saltbush transplants between positions for the grubbed and check treatments were small and nonsignificant. Survival in succeeding years was significantly higher on grubbed plots than on either sprayed or check plots, although only $13 \%$ of the transplants were still alive on the grubbed plots in June 1969.

\section{Seed Spots}

Establishment of fourwing saltbush from seeds planted in the

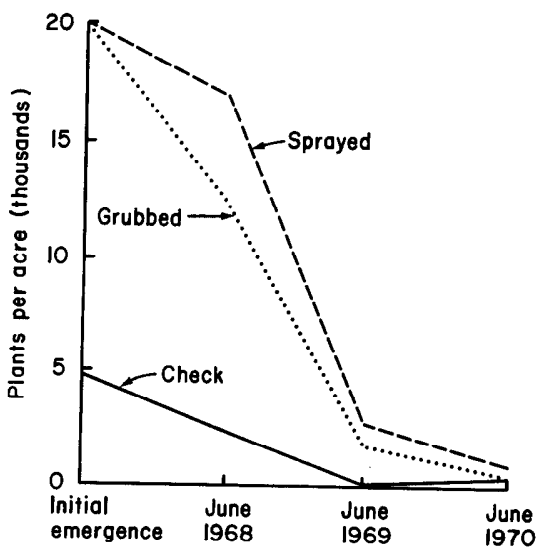

Fig. 3. Survival of fourwing saltbush plants from direct seeding on plots where creosotebush was killed by spraying and grubbing, compared to check areas (creosotebush alive) (seeded January 1968).

seed spots was much poorer than survival of the transplants. Only 39,38 , and 33 live saltbush seedlings were counted on the 180 seed spots of the sprayed, grubbed, and check areas, respectively, the first June (1966) after planting. By June 1967, only 8 plants were alive on all 540 seed spots.

Residual picloram toxicity in the soil under the creosotebush plants was very evident. Five months after the sprayed plots were seeded, only one live saltbush seedling was found under the plants, compared to 8 at the edges of the crowns and 30 in the open (difference on open vs edge + under highly significant).

\section{Direct Seeding (1968)}

Establishment and survival of fourwing saltbush from direct seeding was better than from seed spots, but not as good as from transplanting. Although about $90 \%$ of the seedlings that initially emerged died during the following two years, there were still about 1000 plants per acre on the seeded parts of the sprayed plots in June 1970 (Fig. 3). For both the 1968 and 1969 counts, survival of saltbush was significantly higher on the sprayed and grubbed plots than on the check plots $(p<0.1)$, and differences between sprayed and grubbed plots were not significant. At first glance 
this might appear to conflict with the transplant data, where survival on the sprayed plots was no better than on the check plots. But the 1968 direct seeding was applied only to openings between shrubs, where residual picloram in the soil was insignificant, and not under the crowns.

\section{Results-Mesquite-Burroweed Site}

\section{Saltbush Transplants}

Only about one-tenth as many saltbush transplants survived from the time of planting in January until June 1966 on this site $(4.3 \%)$ as on the creosotebush site $(38 \%)$. No valid comparisons between treatment conditions are possible. Only one saltbush transplant was alive in June 1967, none in June 1968.

\section{Seed Spots}

Establishment and survival of saltbush planted in seed spots was even poorer than for transplants. On 720 seed spots only 20 live seedlings were lound 5 months after planting (average of one for each 36 seed spots, compared to one for every 5 on the creosotebush site). Eight plants were alive in June 1967, none in June 1968.

\section{Direct Seeding (1968)}

Establishment and survival of saltbush from direct seeding in January 1968 , although only $10 \%$ to $20 \%$ as effective as on the creosotebush site, was sufficient to permit limited comparisons (Fig. 3 and 4). Initial emergence of saltbush seedlings was significantly higher (3 times as high) on plots where mesquite was not killed than on plots where mesquite was killed, but was significantly higher on plots where burroweed was killed by spraying or grubbing than where burroweed was not killed. About $50 \%$ of the saltbush plants that initially emerged died in the first 5 months, and by 1970 only two live plants were found, representing a density of about 46 plants/acre, compared to about 650 plants/acre

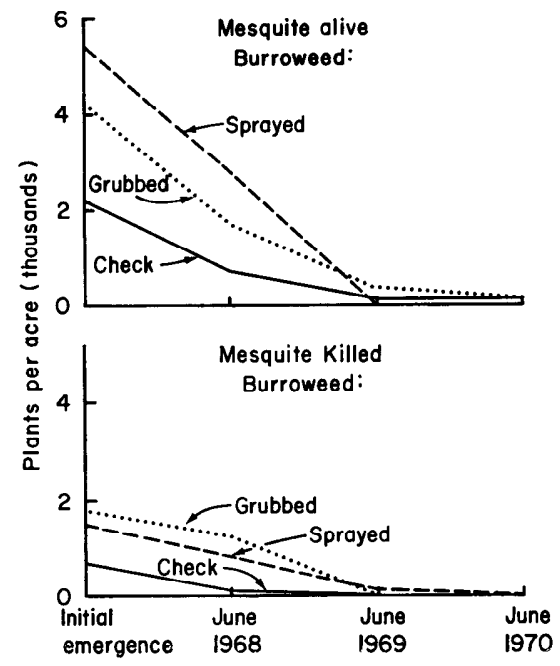

FIG. 4. Survival of fourwing saltbush plants from direct seeding on plots with and without live mesquite, and where burroweed was alive, killed by chemical spray, and grubbed. (Seeded January 1968).

on the creosotebush site (means of all treatments).

\section{Discussion and Conclusions}

The poor survival of saltbush plants in this study does not necessarily mean that saltbush will not grow on these areas. It does indicate a need for better planting methods possibly including moisture conservation measures such as pitting and mulching (Springfield, 1970). Even with the best of methods unfavorable weather can cause poor germination or high seedling mortality. Low winter precipitation in $1966-67 \quad(55 \%$ and $71 \%$ below the long-time averages on the creosotebush and mesquite-burroweed areas respectively) and in 1968-69 (29\% and 38\% below average) could have contributed significantly to the high mortality.

Differences in the chemical and physical nature of the soil between the two study sites undoubtedly were responsible for some of the differences in establishment and survival. The main soil differences were that: (1) the creosotebush area was calcareous throughout the profile ( $\mathrm{pH} 8.0$ or above), while the mesquite-burroweed soil was neutral in the surface with gradually increasing alkalinity with dcpth, (2) the creosotebush soil was a sandy loam throughout the profile while that on the mesquite-burroweed area was clay loam or clay below about 6 inches. At any rate, poor survival of saltbush on the Eba soils and the lack of native saltbush in the vicinity suggest that it is not well adapted at the mesquite-burroweed site. The relatively better survival and the presence of occasional natural saltbushes mixed with creosotebush indicate more promising possibilities at the creosotebush site.

The effects of rabbits and rodents were not specifically measured but repeated clipping near the ground was obvious on many saltbush plants. This suggests the need for control of rabbits and rodents on plantings of saltbush as has been suggested by many previous workers including Wilson (1928) and Springfield (1970).

Early establishment of saltbush was significantly restricted by the presence of either creosotebush or burroweed. The reason for higher emergence of saltbush on mesquitealive than on mesquite-killed plots is uncertain, particularly in view of the well-documented ability of mesquite to use available soil moisture at the expense of associated species.

\section{Literature Cited}

Glemmons, Stan, and L. D. Wheeler. 1970. Soils report for Santa Rita Experimental Range, Coronado $\mathrm{Na}$ tional Forest, Southwestern Region, Forest Serv. U.S. Dep. Agr. 41 p. Albuquerque, N. Mex.

Kearney, Thomas H., and Robert H. Peebles. 1951. Arizona flora. Univ. Calif. Press, Berkeley and Los Angeles. 1032 p.

SPRingfield, H. W. 1969. Temperatures for germination of fourwing saltbush. J. Range Manage. 22: 49-50.

Springfield, H. W. 1970. Germination and establishment of fourwing salthush in the Southwest. IJSDA Forest Serv. Res. Pap. RM-55, 48 p. Rocky Mt. Forest \& Range Exp. Sta., Fort Collins, Colo.

Wilson, C. P. 1928. Factors affecting the germination and growth of chamiza. New Mex. Agr. Exp. Sta. Bull. 169, 29 p. 